\title{
The Self-Management of Special Allocation Fund for Education Sector in South Timor Tengah District in 2017
}

\author{
Lodovikus W. Ignasius Tupen* Petrus de Rosary Leny M. Tamumu \\ Graduate Program of Administrative Studies, Graduate Program, \\ Universitas Nusa Cendana Kupang, East Nusa Tenggara, Indonesia
}

\begin{abstract}
This research was conducted to investigate and describe; (1) the mechanisms of planning, organization, implementation, supervision and accountability evaluation on self-management of Special Allocation Fund (SAF) or Dana Alokasi Khusus (DAK) for education sector in South Timor Tengah Regency. (2) Factors that support and inhibit the self-management of SAF for education sector in South Central Timor District. This qualitative research was carried out in the form of case study. The focuses of this research included; (1) The SelfManagement Planning of the SAF in TTS District; (2) Organization in the self-management of SAF for education sector in TTS District; (3) Implementation of the self-management of SAF for education sector in TTS District; (4) Supervision in the self-management of SAF for education sector in TTS District; (5) Accountability of in the self-management of SAF for education sector in TTS District; (6) Factors that supported and inhibited in the self-management of SAF for education sector in TTS District. Research informants were purposively selected, while the research data were collected through interviews, documentation, and observation. The obtained data were then analyzed using a data analysis technique proposed by Miles and Huberman (2009). The results of this research showed that the management mechanisms (planning, organization, implementation, supervision, and accountability evaluation) of self-management of SAF for education sector in TTS District has been running well. However, several inhibiting factors were found in its implementation which factors mainly dealt with the problems related to inadequate school principal's managerial ability in managing the fund based on the self-management system. The most fundamental problem in this context related to the failure to complete the works within the predetermined schedule. This problem occurred due unprofessional workers and low discipline in working within the predetermined time. In addition, the sanctions for school principals and treasurers did not do their job well were not strict. Other inhibiting factors included problems related to the topographical and geographical conditions in TTS District which often caused slower work pace. The inefficient process in determining the school principals also caused delays in management of Self-Managed SAF.
\end{abstract}

Keywords: Management, Special Allocation Fund, Education, Self-Management

DOI: $10.7176 / \mathrm{PPAR} / 9-11-01$

Publication date: November $30^{\text {th }} 2019$

\section{BACKGROUND}

The main objective of the SAF policy is to fund regional programs based on national priorities, specifically to finance the needs for standard basic public services and infrastructures in order to accelerate the regional development. SAF is expected to reduce disparities in education services between regions and improve the function of regional governments in utilizing the available resources. Therefore, SAF is directed to assist regions which financial capacity is considered lacking to be able to build proper physical facilities and infrastructure for better basic public services.

The policy regarding Special Allocation Funds (SAF) in the field of education was first issued in 2003. Based on the Decree of the Minister of Finance of the Republic of Indonesia Number 544 / KMK.07 / 2002 dated December 31, 2002 concerning the special allocation of non-reforestation funds in the 2003 fiscal year, SAF for Education Sector is allocated to support the implementation of compulsory basic education (Wajar Dikdas) with the main focus on funding the rehabilitation of elementary school (SD) and Madrasah Ibtidaiyah (MI) buildings.

Along with the increase in the number of programs funded by SAF in the field of education, the amount of budget allocated for this sector also significantly increased. In 2003, the government provided 625 billion rupiah for the SAF for education sector. In 15 years, the amount continued to grow and reached 105.9 trillions in 2017.

From 2006 to 2010, the implementation of this program was carried out in a self-management system run by schools. However, the implementation did not properly run as many problems occurred, even caused loss of lives. Therefore, in 2011 the implementation of SAF was conducted through an auction mechanism. This system requires the Education Office to appoint an auction committee to select the construction service provider to carry out the construction jobs. The implementation of the SAF program through an auction mechanism only lasted for 1 year. The Central Government spotted budget inefficiency within this system. Hence, starting in 2012 up to the recent time, the construction work system was returned to self-management system carried out by schools. 
TTS District has been receiving SAF for education sector from 2011 to 2017 to be allocated for the rehabilitation of classrooms, construction of new classrooms, construction of library rooms, construction of laboratory rooms, construction of student and teacher latrines, procurement of library book collections, procurement of learning media, procurement of science and mathematics toolkit and the provision of physical education, sports and health equipment (PJOK) as well as cultural arts. The amount of SAF for education sector in the last 7 years allocated for TTS District is presented in Table 1:

Table 1. SAF for Education Sector for South Timor Tengah District

2011-2017

\begin{tabular}{|c|c|r|r|r|r|}
\hline No & $\begin{array}{c}\text { Tahun } \\
\text { Anggaran }\end{array}$ & $\begin{array}{c}\text { Jumlah DAK SD } \\
(\mathbf{R p})\end{array}$ & $\begin{array}{c}\text { Jumlah DAK SMP } \\
(\mathbf{R p})\end{array}$ & Jumlah (Rp) & Naik/Turun \\
\hline 1. & 2011 & 22.313 .907 .900 & 2.453 .862 .300 & 24.767 .770 .200 & \\
\hline 2. & 2012 & 13.698 .878 .000 & 9.554 .241 .946 & 23.253 .119 .946 & $(1.514 .650 .254)$ \\
\hline 3. & 2013 & 10.556 .208 .987 & 16.308 .836 .918 & 26.865 .045 .905 & 3.611 .925 .959 \\
\hline 4. & 2014 & 13.049 .035 .850 & 5.145 .810 .000 & 18.194 .845 .850 & $(8.670 .200 .055)$ \\
\hline 5. & 2015 & 7.717 .208 .000 & 8.247 .249 .000 & 15.964 .457 .000 & $(2.230 .388 .850)$ \\
\hline 6. & 2016 & 6.601 .310 .000 & & 6.601 .310 .000 & $(9.363 .147 .000)$ \\
\hline 7. & 2017 & 9.036 .362 .800 & 8.310 .000 .000 & 17.346 .362 .800 & 10.745 .052 .800 \\
\hline & & $\mathbf{8 2 . 9 7 2 . 9 1 1 . 5 3 7}$ & $\mathbf{5 0 . 0 2 0 . 0 0 0 . 1 6 4}$ & $\mathbf{1 3 2 . 9 9 2 . 9 1 1 . 7 0 1}$ & \\
\hline
\end{tabular}

Source : Processed Data

The total amount of SAF for education sector allocated by Central Government to the TTS Regency for the past 7 years reached Rp. 132,993,911,701, - With proper management, this amount would have given significant positive effects on the improvement of education quality in TTS Regency. As presented in the table, the amount of SAF allocated in 2011 by the Central Government to the TTS Regency Government reached Rp. $24,767,770.00$, - which amount was used for the the constructions of Elementary and Junior High Schools, new classrooms, procurement of school furniture and the provision of books and the provision of student experimental equipment. The amount of SAF in 2012 decreased slightly Rp. 1,514,650,254 which fund was used for classroom repair and the provision of practical toolkit for students. The amount increased again in 2013 as much as Rp. 2,097,275,705, - which was used to repair classrooms, construct new classrooms, libraries, laboratories and student latrines. The total amount of SAF allocation has continued to decline from 2014 to 2015 due to the remaining fund from the previous year. In 2016, the Central Government only allocated SAF for elementary schools to finance classroom repair activities and PJOK equipment procurement based on several considerations regarding changes in some macro assumptions and state revenue targets caused by domestic and global conditions that eventually changed the state budget for Fiscal Year of 2016. This policy has caused reduce to the amount of fund transferred to the regions, while the amount of fund for village development was increased. In 2017, the SAF allocated for TTS District was twice higher in amount compared to the previous year which was then used for classroom rehabilitation, construction of new classrooms, construction of libraries, laboratories, student latrines, procurement of library books, procurement of learning media and procurement of PJOK equipment and cultural arts.

The fluctuation in the amount of SAF allocated for education sector for TTS District was influenced by several factors. One of them was regarding the management of SAF self-management system carried out by stakeholders of the Education Office including the Head of the Office of Education, Head of Division and Section Heads, Committees (PPK) of SAF Self-Management in 2017, Technical Teams, Principals, School Committees and P2S. Currently, problems occured regarding how far the implementation of SAF programs in education could support learning activities in schools, program planning mechanism, the SAF distribution mechanism, SAF program organization, realization of SAF and the implementation of SAF. SAF allocated for the Field of Education to construct facilities and infrastructure in schools obviously brought benefits for the schools to improve the teaching and learning processes. The fund also brought economic effects to the local community around the school as they could work in the constriction jobs. On the other hand, the use of SAF for the Education Sector required good management by school principals and teachers. This additional duty might affect the performance of school principals and teachers in carrying out their main teaching duties.

The amount of SAF allocated for Education Sector in 2017 Fiscal Year for construction projects reached Rp. 
$12,3655,053,000$, - which fund was managed under self-management system by P2S, while the procurement of practical and library books amounting to Rp. 3,262,957,647, - was managed through an auction mechanism based on Presidential Regulation Number 54 of 2010 concerning the procurement of government goods and services along with the rules for amendments and derivative rules. The realization of SAF for Education Sector in 2017 has almost reached $98.81 \%$.

The utilization of the budget to carry out construction projects of school buildings has run well. However, in the implementation process, some P2S members showed inadequate performance which then caused delays. This problem prolonged the disturbances toward teaching and learning activities at schools. Delays were caused by late completion of jobs which did not go well with the predetermined time schedule specified in the work contract. The problem was also caused by inadequate managerial ability, technical ability and accounting ability of the PPK in managing the SAF. School principals as the person in charge to control the management also showed weak roles. In addition, topographic factors of the TTS District, including the isolated location of the schools and the technical planning process delay by the technical team also added up to the problem. There were 25 elementary schools and 19 junior high schoolst hat received the SAF through Self-Management system in 2017. The implementation of SAF in 25 elementary and junior high schools ran properly, while the one in 9 elementary and junior high schools was poor.

This research was conducted to investigate and describe; (1) the mechanisms for planning, organization, implementation, supervision and accountability evaluation on the use of SAF based on self-management system for education sector in South Timor Tengah District. (2) Supporting and inhibiting factors toward the management of SAF based on self-management system in the Field of Education in South Timor Tengah District. It is expected that this research provide benefits, including theoretical benefits and practical benefits. In terms of theoretical benefits, this research is expected to give valuable contributions to the improvement of education sector, especially in the field of management. While in terms of practical benefits, this research is expected to provide; (1) insights, and knowledge for teachers regarding self-management system in the management of SAF allocation for education sector. (2) insights and rationale for the government in allocating SAF for the field of education appropriately. (3) ideas and considerations for future researchers to conduct further development, and provide valuable references to conduct similar research.

\section{LITERATURE REVIEW}

\section{The Concept of Management}

Siagian (2003: 5) defined management as the process of carrying out various activities in order to achieve certain objectives and it also refers to the abilities or skills of people occupying managerial positions to achieve certain goals through the activities done by other people".

According to Hamalik (2007), management is a social process that deals with the overall effort of humans with the help of other human beings and other sources and the utilization of efficient and effective methods to achieve predetermined goals.

Hasibuan (2017: 2) added that management is the science and art of regulating the process of utilizing human resources and other resources in effective and efficient manners to achieve a certain goal."

\section{The Functions of Management}

George R. Terry (1958 in Sukarna, 2011: 10) classified four basic functions of management, namely Planing (Planning), Organizing (organizing), Actuating (Implementation) and Controling (Supervision). These four functions are abbreviated as POAC as follows; (1) Planing (Planning); Planning refers to the selection and linking of facts and the making and use of future estimation or assumptions done by describing and formulating the activities needed to achieve the desired results. (2) Organizing; Organizing is the determination, grouping and arrangement of various types of activities needed to achieve the predetermined objectives, placement of people (Employees), provision of physical factors needed for the work, and the delegation of authority to certain people in relation to the implementation of the planned activity. George R. Terry in Sukarna (2011: 46) also argues about the principles of organizing as follows: the objective, departmentation (division of labor), assign the personnel (placement of labor), authority and responsibilityand delegation of authority. (3) Actuating (Implementation or mobilization); Implementation refers to the activity done to enhance and encourage all members to be willing and trying hard to achieve the predetermined goals with sincerity based on the predetermined plans and organized works set by the leaders. The definition above shows that the success or failure in achieving certain goals depends on whether all members of the management group willing to make movement, including those who are at the top level, middle to bottom ones. All activities should be directed to achieve the predetermined targets. It should be kept in mind that any activities that are not directed to the target are a waste of labor, money, time and material or in other words a waste of tools of management. This condition is referred to as mis-management. The achievement of objectives depends not only on good planning and organization but also on appropriate implementation and supervision. Planning and organizing are only a strong 
foundation for the implementation. Implementation without proper planning might not run effectively because its success is determined by good the planning, objectives, budget, standards, work methods, procedures and programs (Sukarna, 2011: 82-83). Some factors affect the implementation process including leadership, attitude and morale, communication (incremental relations), incentive, supervision and discipline. (4) Controling; Supervision can be formulated as a process of determining what must be achieved, namely standards (measures), implementation, implementation assessment, and improvements that make implementation run based on the predetermined plans and standards. Supervision has a very important role as it measures whether certain work has been orderly implemented based on the target. Without organized and well-ordered work, good planning, organizing and implementation would not be able to achieve the predetermined goals. Therefore, supervisors are in duty to oversee all activities to make sure that everything done is directed to the target to achieve the predetermined goals.

George R. Terry in Sukarna (2011: 116) proposed several steps of supervision as follows: determining the standard or basis for control, measuring the implementation, comparing the performance with the standard and ascerting the differences and correcting any deviations with appropriate means of action.

\section{Elements of Management}

George R. Terry (in Herujito, 2006: 6-7) mentioned six main resources in the context of management namely: men and women, materials, machines, methods, money and markets. The management element consists of "7M $+1 \mathrm{~L}$ " according to Henry Fayol (in Husaini, 2009) $6 \mathrm{M}$, as follows: man (Human), acting as manpower in the organization or company, needed to lead, move employees / subordinates, and provide energy and mind for the progress and continuity of the institution. Human resource can also be instilled as leadership or entrepreneurship, material (goods), materials used as production processes in a company or organization which might consist of raw materials, semi-finished materials, or finished goods, machines (machines) that are major necessities of an organization. Machines refers to the equipment used by an organization including modern and conventional equipment or equipment such as natural resources and money. Money/capital is classified into 2; fixed capital in the forms of land, buildings, machinery and working capital in the form of cash, accounts receivable, method (election), selection and the use of appropriate methods to avoid inefficiency and waste of resources. Market is a meeting place for sellers and buyers in making transactions and minutes (time) is the measure of time for an institution to effectively and efficiently achieve its vision and the mission.

\section{School Management}

Mulyasa (2007: 24) stated that school management refers to the delegation of broad autonomy at the school level within the framework of national policy. With the granting of autonomy, schools have the authority to manage their own resources including financial resources to be allocated based on their own priority needs and it allows schools to be more responsive toward the fulfilment of local needs.

School Management according to Suparman (2001: 1) is the harmonization of resource utilization carried out independently by schools by involving all relevant parties in decision making process to understand certain quality needs of the school or to achieve certain quality objectives of the school regarding national education.

Umaedi (2002: 3) also explained that School Management is a management model that gives school greater autonomy and encourages participatory decision making processes which directly involve all school members (teachers, students, principals, employees, students and community) to improve school quality based on the national education policy. Management of education according to Redja Mudyahardjo (2002: 105) is a study of strategies that should be taken to regulate the implementation of educational events in an education unit (micro education) or an aggregate unit of education units (macro education). Mulyasa (2005: 19) quoting from Gaffar asserted that education management is a systematic, systemic and comprehensive collaborative process that aims to achieve the goals of national education".

\section{The Characteristics of School Management}

The characteristics of School Based Management according to Hanif (2002: 2) are; (1) The availability of broad autonomy at the school level, (2) Active community participation in the education process, (3) Democratic, fair, upholding accountability and transparent decision making process related to every educational activity, (4) Effective utilization of resources (5) Better understanding and comprehension of specific roles and responsibilities (6) Adequate support from the bureaucracy / supervisor, (7) Improving the performance of the dissemination of SBM concepts, training, implementation of learning process, evaluation and improvement in the field of education.

\section{The Components of School Management}

According to Mulyasa (2007: 52) the most important thing in the implementation of School Management is the management its components including; (1) Management of curriculum and teaching programs; including 
planning, implementation and evaluation of curriculum activities which is needed to ensure the effectiveness of curriculum development and teaching programs. As the manager, school principals should carry out school programs along with the teachers and describe the curriculum content in more detail and operatiol ways in the form of annual, quarterly and monthly programs. (2) Management of education staff to have more effective and efficient roles in achieving optimal results in pleasant conditions. The management of education staff includes; (a) Employee planning, employee recruitment, employee termination. (3) Compensation; a remuneration provided by schools to their employees which can be valued in the form of money given on a regular basis. (4) Student management; the arrangement and regulation of activities related to students, from the beginning up to the end of the school sessions, (5) Financial management and financing; in organizing education, finance and financing are decisive potentials and important parts of school management. (6) Management of educational facilities and infrastructure; regulating and maintaining educational facilities and infrastructure to give maximum contribution to the education process. (7) Management of school relationship with the community; the relationship between the school and the community is imporant to foster and develop the students' personalities at schools. (8) Management of special services; the school as an educational unit is also tasked with and responsible for carrying out the learning process in addition to the responsibilities to develop students' knowledge, skills, and attitudes as well as maintaining and improving the physical and spiritual health of students.

\section{SAF for Education Sector}

According to Kuncoro (2004: 34) Special Allocation Funds are meant to finance special areas for special purposes. Therefore, the fund from the central government is entirely under the authority of the central government to be used for special national objectives. These special needs are in accordance with the functions set in the State Budget. Article 1 of the Act Number 23 of 2014 concerning Regional Government states that the Special Allocation Fund, hereinafter abbreviated as SAF, is a fund sourced from State Budget allocated to certain regions to fund special activities which constitute Government Affairs which become the authority of the Region.

The implementation of SAF itself is directed at investment for development programs, procurement programs, improvement of physical facilities and infrastructure for better community services with long economic life, including the provision of physical facilities and excluding capital investment. For example, the use of SAF in education includes: rehabilitation of school buildings / classrooms, procurement / rehabilitation of sources and sanitation for clean water and bathrooms and toilets, procurement / repair of class room furniture and library cabinets, construction / rehabilitation of school guard houses / teachers / head offices; and improving the quality of schools by constructing / providing library facilities and better infrastructure as well as other educational facilities in schools.

The SAF policies can be divided into 4 large groups, namely (1) determination of programs and activities, (2) calculation of SAF allocations, (3) direction and utilization of SAF programs, and (4) administration of SAF management. In general, the purpose of SAF is to fulfill primary and secondary education facilities and infrastructure in order to improve access and quality of education services.

Cccording to Presidential Regulation No. 123 of 2016 concerning the Physical SAF Technical Guidelines for 2017, the fund was specifically aimed at: (1) Providing learning spaces / other supporting spaces that are comfortable and safe for learning processes; (2) Fulfilling the needs of new classrooms based on the standard educational facilities and targets; (3) Providing better infrastructure for better learning quality by developing science laboratories in junior and senior high schools; (4) Providing facilities for better learning quality by providing more library book collections for elementary schools, provision of educational tools and / or educational media for junior and senior high schools; (5) Providing facilities and infrastructure to facilitate competency practice activities and teaching factory practices for vocational schools.

Arsana (2016: 294) stated that the implementation of the Special Allocation Fund for Education Sector requires the development of educational infrastructure to be carried out independently by $\mathrm{P} 2 \mathrm{~S}$ in accordance with statutory provisions. P2S consists of school elements and the community around the school that are selected and formed through deliberation in the form of school meeting forum.

\section{RESEARCH METHOD}

This research was conducted in the form of qualitative research in the form of case study. The focus of this research included; (1) SAF Self-Management Planning in TTS District; (2) Organization of SAF SelfManagement in the District of TTS; (3) Implementation of SAF Self-Management in the District of TTS; (4) Supervision of of SAF Self-Management in the District of TTS; (5) Accountability of $t$ of SAF SelfManagement in the District of TTS; (6) Factors that support and hinder the management of SAF selfmanagement in the Field of Education in TTS Regency. The informants in this study were selected through a purposive sampling technique based on certain criteria including the Education and Culture Office, the TTS 
Regency and the School Construction Committee. This research regarded both primary data and secondary data which were collected through interviews, documentation, and observation. The obtained data were then analyzed using the analysis technique proposed byMiles and Huberman (2009: 16-19) which steps included data reduction, data presentation, and drawing conclusions.

\section{RESEARCH RESULTS AND DISCUSSIONS}

This research was conducted to examine the management of Special Budget Allocation Fund Management in 2017 in TTS District which was carried out by the Special Allocation Fund Management Team and School Development Committee. The management of the fund included the planning stage of the Special Allocation Funds based on Self-Management system, the organization of the Special Allocation Funds based on SelfManagement system, the implementation of the Special Allocation Fund, evaluation of the Special Allocation Funds based on Self-Management system and the accountability of the Special Allocation Funds utilization.

\section{The Planning of SAF Based on Self-Management System}

The early phase of planning stage, school principals along with school operators completed the data in the DAPODIK application related to the condition of the facilities and infrastructure of the schools. The TTS Regency Education and Culture Office and the TTS Regional Development Planning Agency proposed the list of prospective recipient schools that would receive the 2017 Special Allocation Funds through the Special Allocation Fund application prepared by the Ministry of Education and Culture to be discussed together with the Ministry of Finance to determine the right amount. Prospective schools that received assistance were verified and validated by the Ministry of Education and Culture and the Regency Government.

In the 2017 Fiscal Year, the TTS Regency received Special Allocation Fund for Education sector development which amount reached Rp. 17,346,362,800. The fund allocated for the construction works reached Rp. 12,3655,053,000. The construction works were independently-managed by School Construction Committees based on Presidential Regulation Number 123 of 2016 concerning Technical Instructions for the Utilization of Special Allocation Fund for Education in 2017 and Regulation of the Minister of Education and Culture Number 9 of 2017 concerning Operational Instructions for the Utilization of the Special Allocation Fund for Education Sector in 2017. The remaining amount Rp.4,981,309,800 was used for procurement of facilities to improve the quality of education by providing practical equipment and student props and procurement of library book collection. Procurement of facilities to improve the quality of education was conducted through auctions based on Presidential Regulation No. 54 of 2010 concerning procurement of government goods and services and its amendments and derivative rules.

The Planning of Special Allocation Fund based on Self-Management started from surveying the location by the Technical Team of the District Education and Culture Office and School Construction Committee. For class rehabilitation work, surveys were carried out to identify the level of damages in the school building. Meanwhile, surveys on class or laboratory construction works were carried out to determine the availability of school land and the legality of land to be used as school buildings. The Technical Team then prepared a technical planning document consisting of work plans and budget plan (RAB). The technical planning documents that had been prepared were collectively verified by fellow members of the Technical Team and were examined by the PPK Officers of the Special Allocation Funds. If the document was deemed to have met the requirements, product approval was then signed by the School Principal as the person in charge of the Management of Special Allocation Funds at the school level and the Head of the Middle School Development Division including the SAF PPK and the Technical Team

\section{The Organization of Works Funded by SAF Based on Self-Management System}

The organization stage began with the formation of the TTS District Level Special Allocation Fund Management Team. The Head of the TTS Regency Education and Culture Office together with the PPK Special Allocation Fund appointed the team consisting of the Head of the TTS Regency Education and Culture Office as the Director of the Programs, the Secretary of the Office / PPK to Manage the Special Allocation Fund as the Person in Charge, Elementary School Development Division and Head of Middle School Development Division as Deputy Activity Director, Elementary School Facilities and Infrastructure Section Head and Junior School Facilities and Infrastructure Section Head, Technical Team and administrative staff as members. The Special Allocation Fund Management Team was established based on the Decree of the Head of the TTS Regency Education and Culture Office Number: DIKBUD. 06.03.02 / 402.A / 2017 concerning the Establishment of the Special Allocation Fund Management Team on June 2, 2017.

The organization phase at the school level began with the establishment of School Development Committees in committee formation meetings attended by the school principals, teachers, school committee, parents, local government and the community around the school. The meetings resulted in agreements on the composition, duties and responsibilities of the School Construction Committee that consisted of School 
Principals, Chairperson, teachers, treasurer (teacher or administrative staff), secretary (School Committee members) and other members including teachers, parents of students and elements of the school committee. The agreement on the establishment of the School Construction Committee was done prior to the Establishment of the School Construction Committee that was determined through the Principal's Decree on the Establishment of the School Construction Committee. The recruitment of workers including local workers and craftsmen was also discussed in the meetings.

\section{The Implementation of Works using SAF Based on Self-Management System}

The implementation of the Special Allocation Fund through Self-Management system started with the dissemination of the fund utilization plan by the District Education and Culture Office, where School Principal, Treasurer and Chairperson of the Committee were invited. Technical guidelines and operational instructions for the SAF utilization were presented. The Inspectorate of the TTS District explained the aspects related to the Accountability of the SAF utilization, while the Head of the District Attorney SoE and the Head of the District Police Chief TTS spoke about how to prevent corruptions in managing the Special Allocation Fund based on Self-Management system. The meeting was closed by signing of documents related to the implementation of the project including the Letter of Assistance Grant (SPPBJ), Integrity Pact, Statement of Ability to Perform Work on Rp. 6,000 stamp duty, work plan, and budget plan (RAB). The Letter of Assistance Agreement (SPPBJ) between the PPK Special Allocation Funds as the PARTY I and the Principal as the PARTY-II regulates the legal basis for the implementation of the project, rights and obligations, the duration of work implementation, distribution of funds, conditions for disbursement of funds, accountability and sanctions and taxation reports. The construction works must be carried out based on self-management system and they should be free from any intervention from outside parties who might want to obtain profits from the projects. All school principals had to sign an Integrity Pact and a Statement of Ability to Perform Work on the stamp duty of Rp. 6,000 known by the Head of the Education and Culture Office of TTS Regency.

The Special Allocation Funds self-management administrative document, work plan, and budget plan (RAB) were submitted to the TTS Regency Regional Financial and Asset Management Agency for the fund transfer process to schools' bank accounts. The funds were disbursed three times in three phases; phase I by $40 \%$, phase II by $30 \%$ and phase III by $30 \%$ by school principals and treasurers baseon on the disbursement recommendation of the SAF signed by the PPK. The funds were managed in NTT Bank SoE Branch and other sub-branches closest to the location of the schools to be disbursed and spent as needed as planned in the Fund Utilization Plan (RPD). Procurement of building materials were obtained from shops in the City and surrounding areas. The construction works stated by the pegging of the work location by the Technical Team together with the School Construction Committee to determine the $0 \%$ point based on the work plan and the budget plan (RAB). The amount of wages for workers and the duration of work were determined. The preparation of accountability reports on the use of the Special Allocation Funds was carried out by the Principals and treasurers assisted by the Technical Team. The Technical Team also helped preparing the weekly and monthly progress reports. As a requirement for the next stage of fund disbursement, accountability reports should be completed with weekly and monthly reports, evidence of expenditure on building materials and proof of payment of the workers' wages, proof of tax payment, upcoming budget plan, visual data and other related documents.

\section{The Monitoring of the Projects Funded by SAF based on Self-Management System}

Monitoring and evaluation were carried out every 2-3 weeks. This frequency was considered inadequate. Supervision conducted by the Technical Team was also considered ineffective because it was not always done when the work process was running. In addition, the supervision also involved the SoE State Attorney apparatus and the TTS Resort Police to make sure that the process was accountable and transparent. When the work has been completed, the School Construction Committee represented by the Principal submitted a letter of application for the final inspection to the TTS District Education and Culture Office. The final inspection involved TTS Regency Inspectorate Auditor. Any inappropriate work had to be properly followed up. Ideally, supervision should have been carried out by a Supervising Consultant. However, due to budget constraints, work supervision was carried out by the Special Allocation Fund Management Team, the Technical Team and the community. This condition caused the implementation of work in the field did not run as expected due to ineffective and inefficiently use of time. As a result, almost all of the works did not run according to the predetermined schedule. Moreover, the lack of technical personnel also caused the delay.

\section{The Accountability Report of the Project Funded by SAF based on Self-Management System}

The next stage was the formulation of administration accountability to prove the accountablity and trasparency in the use of SAF in the forms of accountability reports consisting of general cash books, bank books, evidence of material purchases and proof of payment of the workers' wages, proof of tax payment, weekly and monthly reports on the construction progress, upcoming budget plan, and visual data. 
The Letter of Assistance Agreement (SPPBJ) article 13 regulates the Responsibility, in which: THE SECOND PARTY must report and account for the Special Allocation Funds for the 2017 Fiscal Year to the FIRST PARTY no later than 14 (fourteen) days starting from the completion of work. These following documents should be reported: (1) Handover Report, (2) Proof of Expenditures (receipts) for every purchase of goods, (3) Proof of Tax Payment and (4) Proof of Technical Work.

The limitations of the School Construction Committee in understanding the technical issues of the building and accounting caused issues in the preparation of accountability report. Therefore, the School Construction Committee was then assisted by the Technical Team of the Education and Culture Office of the TTS Regency to prepare the report. The principal and treasurer collected expenditure receipts and proof of payment of the workers' wages to be compiled with Technical Team. School principals and treasurers who were experienced in managing the work did not find the process difficult, However, less-experienced ones found the work difficult that they needed the assistance of a Technical Team to organize the administration of the work. The budget plan had actually been submitted in the accountability reports handed to the School Construction Committee, but school principals and treasurers still faced difficulties in preparing accountable and transparent reports.

\section{Supporting and Inhibiting Factors of the Project Implementation Funded by SAF based on Self- Management System}

The uptake of Special Allocation Funds for the 2017 Fiscal Year reached 98.29 percent. This indicated that the project held by the TTS District was quite successful. This could be achieved since the cooperation between the School Development Committee and the District-level Special Allocation Fund Management Team in terms of planning and implementation in the field was adequate. In addition, support from the District Government in the process of fund disbursement to school accounts also ran well. The procedure for disbursing the Special Allocation Funds was also conducted by creating new bank accounts for schools assisted by the NTT Bank SoE Branch and other Supporting Branches. The management fund disbursement and the preparation of the RAB and work plan was carried out by the technical team and preparation of financial accountability reports was assisted by the technical team. In addition, technical guidelines and operational instructions were not difficult to understand by the School Construction Committee and the District Level Special Allocation Fund Management Team. Compared to the previous project implementation, the one conducted in 2017 was supported by the 5\% fund available from the total Special Allocation Fund for Education for the District of TTS to make the implementation run well based on the Self-Management system.

The most fundamental inhibiting factors in the implementation of the project was related to the lack of managerial ability of school principals. The completion of the work was often late due to recruitment of workers who were not professional and well-disciplined in carrying out the work as scheduled. In addition, the imposition of sanctions for school principals and treasurers who were negligent in carrying out their work was also inadequate. Other inhibiting factors were related to topographical and geographical conditions of TTS District which also caused delays. In addition, the late determination of school principals in charge also caused this delay.

\section{CONCLUSIONS}

Regarding to the results and discussions, conclusions on the implementation of the SAF funded Projects based on Self-Management System of the 2017 Fiscal year in TTS District were drawn as follows.

1. The project funded by SAF through self-management system started with the proposal of the recipient schools done by the TTS Regency Education and Culture Office and the TTS Regency Regional Development Planning Agency through the application of the Special Allocation Fund Menu to the National Development Planning Agency to be discussed with the Ministry of Finance. The discussion resulted in the determination of the amount of the budget. Verification and validation of the data were conducted by the Ministry of Education and Culture, the TTS Regency Regional Development Planning Agency and the TTS Regency Education and Culture Office. After that, dissemination on the use of the Special Allocation Fund through Self-Management System was conducted with school-level Special Allocation Funds Managers and the TTS Regency Education and Culture Office's Special Allocation Fund Management Team, the TTS Regency Inspector, the SoE Kejari and Head of Resort Police of TTS. In the planning stage, surveys to potential beneficiary schools were carried out and the preparation of technical planning products in the form of work plan and budget plans (RAB) were prepared by the Technical Team and School Construction Committee.

2. The organization of the project started from the establishment of a School Construction Committee through a meeting to appoint School Construction Committee attended by teachers, school committees, parents and local village government officials. In the meeting, the composition of duties and responsibilities of the School Construction Committee including the persons in charge; principal, teacher or administrative staffs appointed as treasurers, and secretary selected from school committee and members from the elements of the teacher, committee and the community were determined. 
School Construction Committees were stipulated by the Principal's Decree whose the duties and responsibilities were described in the Operational Directive for the Implementation of Special Allocation Funds for Education.

3. The implementation of Self-Management was done based on self-management system by School Construction Committee The time schedule for carrying out the work was specified in the Letter of Assistance Agreement which should have been completed within 120 days. The predetermined time had been considered sensible, yet almost all School Construction Committees failed to complete the work on time due to the poor performance of the workers. In general, the implementation of the project in TTS District ran well as shown by the absorption of the Special Allocation Fund for 2017 that reached $98.26 \%$.

4. Monitoring and evaluation were carried out by the TTS District Education and Culture Management Team, Technical Team, PPK, Police and Attorney Office. At the time of the final inspection, the results of the inspection were examined by Auditor of the TTS Regency Inspectorate. The intensity of monitoring and evaluation for 2-3 weeks down to the school location was considered less effective. This problem then caused less optimal work completion and use of materials that did not meet the job specifications. In addition, due to ineffective supervision, the schedule could not be completed on time as agreed.

5. The accountability report consisted of the general book, valid payment receipts, tax payment receipts, budget plan, weekly and monthly report of the work in progress and pictures. The preparation of this accountability report was inhibited by the lack of comprehension of the school committee on accounting aspects and technical works. Therefore, the technical team provided assistance in the preparation of the report.

6. The most basic inhibiting factor was related to the limited managerial ability of the school principles in managing the project funded by SAF based on the self-management system. Most of the works were not completed on time as scheduled in the letter of agreement due to the recruitment of less professional workers who had low self-discipline. The punishment given to school principles and treasurers who did not perform good was also inadequate. Another inhibiting factor was related to the topographic and geographical condition of TTS district that caused the delays. The relatively longer time in determining the definitive school principals also caused this delay.

\section{SUGGESTIONS}

Based on the results of this research, suggestions were proposed as follows.

1. It is suggested that some projects in education sector funded by SAF are implemented using self,management system, yet other alternative system should be applied to projects that are considered more effective and efficient when they are handled by professional contractors. The Department of Education and Culture of TTS District is encouraged to file request to the Ministry of Education and Culture to revise the technical and operational guidelines to provide more alternatives other than selfmanagement system.

2. The monitoring of the construction work should be enhanced in order to build high-quality building. The Department of Education and Culture of TTS District is suggested to recruit professional facilitator to handle the monitoring of the project.

3. The Department of Education and Culture of TTS has to perform technical advisory to those who manage the SAF at school level to make sure that everyone understand about the utilization of the fund based on the self-management system. However, the dissemination of this information within a day was not considered effective enough in enhancing the comprehension of the related parties regarding to the management of the SAF based on the self-management system.

4. The Department of Education and Culture of TTS district should apply strict punishment to irresponsible persons-in-charge for the implementation of the projects funded by SAF based on the legislation and discontinue the project given to the particular school.)

5. It is also suggested that The Department of Education and Culture of TTS district give suggestions to the Ministry of Education and Culture related to the needs of more comprehensible Technical and Operational Guidelines to the utilization of SAD for multiyear in order to accelerate the process.

\section{REFERENCES}

Arsana,I Putu Jati. 2016. Manajemen Pengadaan Barang dan Jasa Pemerintah. Deepublish. Yogyakarta. Hamalik, Oemar. 2006. Proses Belajar Mengajar. PT. Bumi Aksara. Jakarta

Hasibuan, S.P. Malayu.2011. Dasar, Pengertian, dan Masalah Manajemen (Ed.Revisi 14,Cet.14). PT.Bumi Aksara. Jakarta.

Kuncoro. 2004. Otonomi Dan Pembangunan Daerah: Reformasi, Perencanaan, Strategi, dan Peluang. Erlangga. 
Jakarta.

Miles, Matthew B. \& Huberman A. Michael. 2009. Analisis Data Kualitatif. Jakarta: UI-Press.

Mulyasa. 2004. Kurikulum Berbasis Kompetensi; Konsep Karakteristik, dan Implementasi. Rodya Karya. Bandung.

Mulyasa. 2005. Menjadi Guru Profesional. PT. Remaja Rosda Karya. Bandung.

Mulyasa. 2007. Menjadi Guru Profesional menciptakan Pembelajaran Kreatif dan Menyenangkan .Bandung : RosSAFarya

Sukarna. 1992. Dasar-dasar Manajemen. CV. Mandar Maju. Bandung.

Herujito, Yayat M. 2006. Dasar-Dasar Manajemen. PT Grasindo. Jakarta

Husaini, Usman. 2009. Manajemen Teori, Praktik dan Riset Pendidikan. Bumi Aksara. Jakarta

Suparman, Atwi M. 2001. Desain Instruksional. PAU-PPAI Universitas Terbuka, Jakarta.

Umaedi. 2002. Pendekatan Kontekstual. Departemen Pendidikan Nasional Direktorat Jenderal Pendidikan Dasar dan Menengah. Direktorat Pendidikan Lanjutan Pertama.

Mudyahardjo, Redja. 2002. Pengantar Pendidikan Sebuah Studi Awal Tentang Dasar-Dasar Pendidikan Pada Umumnya Dan Pendidikan di Indonesia. PT. Raja Grafindo Persada, Jakarta.

Hanif, Nurcholis. 2002. Pertumbuhan \& Penyelenggaraan Pemerintahan Desa. Jakarta: Erlangga 